\title{
Akulturacja studentów międzynarodowych w trakcie pandemii COVID-19
}

Streszczenie: W niniejszym artykule przedstawiono oddziaływanie pandemii COVID-19 na akulturację i strategie akulturacyjne studentów międzynarodowych w UE, USA i Australii. Pandemia wyostrzyła trudne i ryzykowne aspekty akulturacji studentów, przyśpieszając ją. Izolacja pandemiczna oraz chaos informacyjny spowodowany pandemią utrudniają badanym przejście od fazy szoku kulturowego do fazy zdrowienia/adaptacji. U tych, którzy przed pandemią zbliżali się do tego etapu, można zaobserwować zatrzymanie adaptacji i przyjęcie strategii wymuszonej separacji. Studenci wybierają strategie akulturacyjne - lub przez pandemię są skazani na takie wybory - które nie wiążą się z budowaniem relacji ze społeczeństwem przyjmującym: separację i marginalizację. Integracja pojawia się jedynie w kontekście relacji z innymi studentami międzynarodowymi, mieszkającymi w tym samym miejscu. Równocześnie studenci wyrażają obawy co tego, czy pandemia i jej skutki umożliwią im dalszą integrację ze społeczeństwem przyjmującym. To z kolei rodzi obawę przyszłego odpływu studentów międzynarodowych z UE, USA i Australii, czemu można zapobiec, zmieniając paradygmat myślenia o miejscu studentów międzynarodowych w systemach wspomnianych krajów.

Słowa kluczowe: studenci międzynarodowi, pandemia COVID-19, akulturacja, strategie akulturacyjne

\section{Wprowadzenie}

Mobilność międzynarodowa, w tym edukacyjna, jest jednym z aspektów zglobalizowanego świata, na który pandemia COVID-19 miała największy wpływ. Dotyczy to m.in. mobilności studentów międzynarodowych definiowanych przez UNESCO jako „studenci, którzy przekroczyli narodowe lub terytorialne granice w celach edukacyjnych i są zarejestrowani w instytucji poza granicami ich kraju pochodzenia" (UNESCO, 2020). Od ogłoszenia 11 marca 2020 roku przez WHO pandemii przeprowadzono liczne badania wskazujące, w jaki sposób wpłynęła ona na mobilność międzynarodową stu- 
dentów. Ze względu na restrykcje związane z podróżowaniem w okresach "lockdownu” wielu z nich miało problemy z powrotem do swoich krajów, co nierzadko stawiało ich w niejasnej sytuacji prawnej. Podyktowane względami bezpieczeństwa zamknięcie administracji akademickiej i instytucji publicznych spowodowało zmniejszenie możliwości sprawnego przeprowadzania procedur związanych z mobilnością, takich jak wydawanie wiz studenckich, pozwoleń na pobyt, przyjęcia na studia lub wymiana studencka.

Pandemia zmniejszyła również szansę studentów międzynarodowych na zarobkowanie podczas studiów (w okresie „lockdownu” wykonywanie większości dostępnych dla nich prac było niemożliwe). Ponieważ ich rodziny w krajach pochodzenia często również zostały dotknięte bezrobociem, nie mogły wspierać zagranicznej edukacji swoich bliskich (European Migration Network, 2020, s. 2). Adepci międzynarodowego studiowania skarżyli się też na większe występowanie problemów lokalowych w trakcie pandemii (Morris et al., 2020, ss. 70-75). Na jej skutek w Europie, Australii i USA wzrosło także występowanie dyskryminacji i rasizmu wobec studentów o azjatyckim wyglądzie, co można tłumaczyć tym, iż wirus pochodzi z Chin (Ka Ho Mok et al., 2020, s. 10; Morris et al. 2020, s. 91-92). Wśród studentów międzynarodowych w trakcie pandemii odnotowano znacznie wyższy - niż przed nią - poziom poczucia samotności, stresu i depresyjności (Misirlis, Zwaan i Weber, 2020, ss. 2-3; Morris et al., 2020, ss. 70-76, 89-90, 92-93).

Opisane problemy wynikają ze sprzężenia w jednym czasie dwóch trudnych sytuacji - przeżywania przez studentów międzynarodowych pandemii COVID-19 oraz procesu akulturacji i związanego z nią stresu akulturacyjnego, w ostrej fazie występującego jako szok kulturowy (Kownacka, 2007, s. 32). Na początku pandemii francuski filozof, socjolog i historyk Marcel Gauchet w wywiadzie dla dziennika Le Figaro powiedział, że jest ona „wyzwalaczem wszystkich defektów”, szkłem powiększającym, uwypuklającym wszelkie dotychczasowe słabości, katalizatorem pęknięć (Devecchio, 2020). Warto więc zadać pytanie: czy pandemia ma wpływ na przebieg akulturacji studentów międzynarodowych? Wszak ich akulturacja to proces obfitujący w trudności i obszary ryzyka szeroko opisywane w literaturze już od lat 50. XX wieku (m.in. Lysgaard, 1955, ss. 45-51; Bochner, McLeod and Lin, 1977, s. 277, 297; Bochner and Orr, 1979, ss. 37-46).

Czy - parafrazując Gaucheta - pandemia staje się szkłem powiększającym, które uwypukla niebezpieczeństwa związane z procesem akulturacji studentów międzynarodowych, i czy staje się katalizatorem ukrytych w nim czynników ryzyka, „wyzwalaczem” defektów instytucjonalnych? W niniej- 
szym artykule podjęto próbę odpowiedzenia na te pytania, opierając się na badaniach dotyczących sytuacji studentów międzynarodowych w czasie pandemii w UE (w tym na badaniach własnych nad studentami programu ERASMUS), USA i Australii, jako że są to trzy najpopularniejsze obszary wybierane przez studentów międzynarodowych ${ }^{1}$. Przeprowadzony przegląd literatury pozwala zauważyć, że do tej pory nie pojawiło się opracowanie naukowe, które poruszałoby problem będący tematem tego artykułu.

\section{Proces akulturacji i strategie akulturacyjne}

Akulturacja to proces wchodzenia w odmienny krąg kulturowy (Brzezińska-Hubert i Olszówka, 2008, s. 19), który można podzielić na etapy: miesiąca miodowego (fascynacja egzotyką przy jednoczesnym pomijaniu różnic międzykulturowych i idealizowaniu nowego kraju); obserwatora (doświadczanie pierwszych trudności wynikających z różnic międzykulturowych, brak zaangażowania w podejmowanie działań, koncentracja na ojczyźnie pochodzenia i porównywanie z nią kraju gościnnego); uczestnika (narastające poczucie zagubienia, niezrozumienia rzeczywistości, utraty kontroli nad swoim życiem, pierwsze objawy silnego stresu); szoku kulturowego (wycofywanie się z kon-

1 Przywołane w pracy analizy naukowe zostały poparte fragmentami wywiadów zaczerpniętych z następujących badań: wykonanych przez: ERASMUS+ i European Solidarity (przeprowadzone 04.2020, obejmowały 11800 odpowiedzi studentów, stażystów, młodych ludzi oraz personelu szkół wyższych przebywających wówczas na wymianach edukacyjnych), European Universities Initiative (przeprowadzone 03-04.2020, wzięło w nich udział 93 respondentów, w tym 17 pochodziło ze stowarzyszeń uczelni wyższych skupiających 114 instytucji akademickich w całej UE), The Erasmus Student Network (przeprowadzone 04.2020, obejmowały 21930 studentów z 125 narodowości pochodzących z UE - głównie Hiszpanii, Włoch, Niemiec, Portugalii i Francji - oraz spoza UE - głównie Turcji, Serbii, Norwegii, Wielkiej Brytanii, Meksyku, Rosji, Ukrainy, Ukrainy i USA. Miejscami mobilności studentów były przede wszystkim uczelnie w Hiszpanii, Włoszech, Niemczech, Portugalii oraz Polsce), badania własne (przeprowadzone 03-06.2020 na 15 wśród studentów programu ERASMUS + w Uniwersytecie Szczecińskim, pochodzących z Włoch, Turcji, Czech, Słowacji, Niemiec, Kamerunu), Ngoc Pham, Juehui Shi (podczas pierwszego „lockdownu” 20 wietnamskich studentów - 8 mężczyzn, 3 kobiety, z uczelni w Nowym Jorku: Brooklyn College, Baruch College, New York University, Long Island University, Kingsborough Community College), Alana Morrisa i innych (podczas pierwszej fali pandemii, badania ankietowe przeprowadzone wśród 751 respondentów, których uzupełnieniem było 26 wywiadów wśród studentów z Sydney i Melbourne). 
taktów społecznych, wybuchy złości, zachowania konfrontacyjne, poczucie bezsilności, somatyzacja stresu); zdrowienia/adaptacji (stopniowa akceptacja odmienności swojej i otoczenia, włączanie coraz większej liczby zachowań adekwatnych kulturowo, większa stabilność emocjonalna); mistrzostwa/ dwukulturowości (odzyskanie kontroli nad swoim życiem, znalezienie kompromisu między kulturą ojczystą a gościnną, nabycie kompetencji do funkcjonowania w nowej kulturze) (Kownacka, 2007, ss. 36-38). Warto zaznaczyć, że przedstawiony tu model akulturacji, przybierający kształt litery „U” (od miesiąca miodowego do dwukulturowości), nie jest jedynym możliwym. Może on mieć przebieg odwrotny (odwrócona litera „U”) - pod wpływem trudnych wydarzeń zdarzają się powroty do wcześniejszych stadiów, a sposób przeżywania akulturacji jest w rzeczywistości bardzo zindywidualizowany.

W zależności od postaw samego migranta wobec nowej kultury, a także sposobu, w jaki traktuje go społeczeństwo przyjmujące, proces akulturacji kończy się przyjęciem jednej z czterech strategii akulturacyjnych: asymilacji (odrzucenie kultury ojczystej na rzecz kultury kraju migracji - najczęściej motywowane chęcią osiągnięcia dobrej pozycji w społeczeństwie niechętnym odmienności); integracji (obopólna akceptacja oraz połączenie cech i wartości obu kultur, autonomiczne podejmowanie decyzji dotyczących tego, z którego kręgu kulturowego wybierać sposoby radzenia sobie z daną sytuacją); marginalizacji (odrzucenie norm i wartości obydwu kultur, utrata kontaktu z własną kulturą przy braku wejścia w nowy krąg kulturowy - może prowadzić do alienacji, utraty tożsamości, problemów natury psychologicznej, zachowań kryminogennych); separacji (oddzielenie się od kultury kraju gościnnego i zamknięcie we własnej grupie kulturowej - często wynika z nieprzyjaznego stosunku względem przybyszów i ich kultury) (Berry, 1995, s. 159). Ważną rolę w kontekście wyboru przez migranta konkretnej strategii akulturacyjnej odgrywa sposób, w jaki traktuje go otoczenie w kraju gościnnym. W czasie pandemii rola tego czynnika zdaje się jeszcze bardziej istotna, gdyż w sytuacji trudnej człowiek szczególnie potrzebuje wsparcia społecznego i mocniej odczuwa jego brak (Kawula, 2012, ss. 153-154).

\section{Proces akulturacji i strategie akulturacyjne studentów międzynarodowych}

Na początku pandemii wielu studentów stanęło przed decyzją: pozostać czy powrócić do domów? Jak wynika z badań przeprowadzonych przez Erasmus Student Network (ESN), moment wyboru był dla badanych najbardziej stre- 
sującą chwilą w trakcie pandemii. Bardzo wysoki poziom stresu i niepokoju - wynikający z braku informacji dotyczących dalszego postępowania - odczuwało w tym czasie 47,5\% z nich (Gabriels and Benke-Aberg, 2020, s. 19-20). Do pozostania w kraju gościnnym skłoniły studentów m.in. pozytywne doświadczenia $\mathrm{z}$ dotychczasowego przebiegu studiowania oraz fakt, że niektórzy $\mathrm{z}$ badanych znajdowali się wówczas w fazie miesiąca miodowego. Obrazują to poniższe wypowiedzi, w których dominuje zachwyt nad nowym krajem przy jednoczesnym szukaniu podobieństw ze znanymi sobie kulturami:

Przez pierwsze dwa cudowne tygodnie nie było restrykcji i mogłem odkrywać miasto, poznawać jedzenie, kulturę, chodzić do kawiarni, restauracji. Jeśli pochodzisz z innej kultury, możesz mieć trudności z przyzwyczajeniem się do jedzenia kraju, w którym próbujesz się zaadaptować. W moim przypadku tak nie było. Zauważyłem, że potrawy zawierające gotowane mięso i warzywa dominują w polskiej kuchni. Spotykamy je często również w kuchni tureckiej. Chociaż lubię polskie potrawy, dla siebie gotowałem dania tureckie, bo tak było taniej. Kupowałem warzywa i owoce na rynku, starałem się mówić do sprzedawców po polsku. Kiedy mówiłem, że jestem z Turcji, prawie wszyscy opowiadali, że byli w Stambule i że jest to bardzo piękne miasto. Byli mili, otwarci i serdeczni. Byłem zachwycony ciepłem bijącym od Polaków [student X z Turcji na wymianie w Polsce] (badania własne).

Jestem tu od września i mój pierwszy semestr w Polsce był cudowny. Mieszkałem wcześniej w Czarnogórze, Bośni i Serbii i łatwo zaadaptowałem się do życia w Polsce między innymi dlatego, że język polski ma pewne podobieństwa do języków południowosłowiańskich. Byłem w stanie dogadać się z Polakami, zwiedzałem kraj, który jest piękny i malowniczy. Bardzo polubiłem Szczecin, który jest cudownym miastem. Spotkałem tu wielu otwartych, interesujących ludzi. Znalazłem pracę $\mathrm{w}$ międzynarodowym środowisku. To był piękny czas [student z Azerbejdżanu na wymianie w Polsce] (badania własne).

Wybuch pandemii zmienił jednak spojrzenie na społeczeństwo kraju gościnnego, które zaczęło nieprzyjaźnie i nerwowo reagować na obcokrajowców. Jak mówi jedna z badanych:

W semestrze zimowym byłam zachwycona otwartością Polaków. Miałam wrażenie, że wszyscy tutaj uwielbiają Włochów i znają włoskie piosenki. To się drastycznie zmieniło podczas „lockdownu”. Kiedy ludzie w sklepie orientowali się, że jesteśmy z Włoch, zaczynali reagować ner- 
wowo, odsuwali się od nas, niektórzy wychodzili ze sklepu. Rozmawialiśmy o tym w akademiku. Okazało się, że z podobnymi zachowaniami zetknęli się studenci o azjatyckim wyglądzie [studentka z Włoch na wymianie w Polsce] (badania własne).

Początek pandemii jako moment, w którym mimo zakładania maseczek "opadły maski" oraz nastąpiła przyśpieszona konfrontacja z prawdziwym obliczem społeczeństw gościnnych i z własnym w nich miejscem, opisują również studenci międzynarodowi w USA. Studentki z Wietnamu, do tej pory oczarowane Ameryką, po wybuchu pandemii decydują się pozostać w tym kraju, licząc na dobrą pomoc medyczną w razie zachorowania. Szybko uświadamiają sobie jednak, że są tam obce. Po utracie pracy wywołanej przez "lockdown” nie przysługują im zasiłki czy pomoc medyczna, z jakiej mogą korzystać obywatele USA. Mówią o tym następująco:

Słyszałam, że zasiłki takie jak Pomoc w Przypadku Katastrof [Disaster Relief Emergency - A.L. Wszystkie wywiady zostały przetłumaczone przez Annę Linkę] przysługują tylko Amerykanom. Ja jestem tutaj studentką międzynarodową (...). Nie otrzymałam pomocy od rządu (...). Wszyscy moi znajomi są w takiej samej sytuacji [studentka A z Wietnamu studiująca w USA] (Pham i Shi, 2020, s. 5).

Muszę sama zadbać o siebie. Tego się nauczyłam. Przed tą pandemią byłam tak pewna, że żyję w najbardziej rozwiniętym kraju na świecie, z najlepszym systemem opieki zdrowotnej (...). Okazuje się, że nie (...). Teraz się boję [studentka B z Wietnamu studiująca w USA] (Pham i Shi, 2020, ss. 5-6).

Doświadczenia z czasu pandemii uświadamiają studentom, że są sami w obcym kraju, który nie jest tak idealny, jak to sobie wyobrażali, i w którym w najtrudniejszych chwilach nie ma przy nich bliskich, na których mogą liczyć w każdej sytuacji:

Jedna z moich koleżanek, kiedy miała gorączkę, dzwoniła na gorącą linię całymi dniami, ale nikt nie odbierał. Wyzdrowiała sama po sześciu dniach (...). To było ekstremalnie przerażające doświadczenie dla niej $\mathrm{i}$ jej rodziny w Wietnamie [studentka $\mathrm{C} z$ Wietnamu studiująca w USA] (Pham and Shi, 2020, s. 6).

Takie zdarzenia powodują tęsknotę za rodziną. Potęguje ją fakt, że na skutek zamknięcia granic spotkanie z bliskimi jest niemożliwe. Jedna z badanych przyznaje: 
Tęsknię za mamą. Nie widziałam jej od roku. Codziennie rozmawiamy przez telefon, ale to nie to samo, wiesz (...). Najsmutniejsze jest to, że nie wiemy, kiedy będziemy mogły się zobaczyć [studentka B z Wietnamu studiująca w USA] (Pham and Shi, 2020, s. 6).

Cytowani studenci przejawiają zachowania typowe dla fazy obserwatora - dostrzeganie pierwszych trudności wynikających z bycia innym, obcym w nieswoim kraju i kręgu kulturowym oraz koncentracja na ojczyźnie i tęsknota za osobami w niej pozostawionymi. Podobne reakcje na początku pandemii identyfikowano u studentów międzynarodowych w Australii. Grupa ta przed pandemią była traktowana $\mathrm{z}$ namaszczeniem, gdyż stanowiła źródło dużych dochodów dla australijskiego szkolnictwa wyższego. Po jej wybuchu zagraniczni żacy nagle skonfrontowali się z faktem, że są na antypodach obcy. Premier Australii Scott Morrison oświadczył im, że „wspaniale jest mieć gości w dobrych czasach", więc dobrze by było, żeby ci, którzy stracili pracę na skutek pandemii i nie mają za co się utrzymać, wrócili do domów i tam otrzymali wsparcie (Nguyen i Balakrishnan, 2020, s. 1). Wskutek pandemii status studentów międzynarodowych w społeczeństwie australijskim stał się niejasny. Badania wskazują, że wywołało to u ponad $58 \% \mathrm{z}$ nich objawy silnego stresu (Morris et al., 2020, s. 90). Jeden z nich mówi o tym następująco:

Pandemia wpłynęła na tyle rzeczy (...). Dano nam możliwość przełożenia studiów, ale wówczas cały rok byłby przełożony, a ty musiałbyś wrócić, a nie wiadomo, jak cała sytuacja będzie ewoluowała. Co, jeśli Australia zamknie granice na zawsze i kiedy będziesz chciał wrócić na studia, nie będziesz mógł tego zrobić i ich dokończyć? Musimy podjąć tyle decyzji, bazując na niewiadomych. Trzeba żyć z dnia na dzień [student międzynarodowy z Uniwersytetu w Melbourne] (Morris et al., 2020, s. 90).

Pandemia buduje mury i wyostrza granice między państwami i narodami. Ci ze studentów, którzy zdecydowali się zostać w Australii mimo poczucia obcości i bycia w zawieszeniu, borykają się z problemami lokalowymi i bezrobociem przy braku lub niewielkiej pomocy uniwersytetów, australijskiego rządu i samorządów. To pogłębia objawy długotrwałego stresu:

Tak, to szaleństwo. Czasami jest tak ciężko, że nie mogę spać, a potem muszę wykonać pracę na uczelni, myśleć i zorganizować każdego dnia takie sprawy, jak spotkania z agentami i negocjowanie w sprawie pracy. Masa rzeczy zbiega się razem [student międzynarodowy z Uniwersytetu w Sydney] (Morris et al., 2020, s. 76). 
Powyższe przykłady obrazują zachowania typowe dla fazy uczestnika, a więc pierwsze przejawy silnego stresu, dezorientacji i zagubienia, zawężanie perspektywy czasowej do najbliższych dni lub tygodni. Stąd tylko krok do szoku kulturowego. Katalizatorem tego etapu jest u części badanych doświadczanie zachowań ksenofobicznych i rasistowskich, których podłoże stanowi lęk, że cudzoziemcy roznoszą COVID-19. Badani mówią o tym następująco:

Przez te dwa tygodnie przez cały czas czuję się, jakby ktoś mnie obserwował, jakbym była zakażona koronawirusem tylko dlatego, że jestem Azjatką. Ktoś na stacji użył wobec mnie spreju dezynfekującego, co mnie bardzo zasmuciło [studentka z Japonii na wymianie w Hiszpanii] (Gabriels and Benke-Aberg, 2020, s. 21).

Jedną rzeczą, która mnie bardzo uderzyła, był fakt, że pewnego dnia weszłam do klasy i moja nauczycielka nie pozwoliła mi zająć miejsca, ale od razu kazała mi się odsunąć, bo jestem Włoszką i według niej mogłam mieć wirusa. Nie miałam kaszlu ani gorączki. Poza tym nie byłam we Włoszech od czterech miesięcy [studentka $\mathrm{z}$ Włoch na wymianie w Portugalii] (Gabriels i Benke-Aberg, 2020, s. 21).

Na takie same zachowania było narażonych 6\% studentów przebadanych przez ESN, głównie Włochów (24\%) i Azjatów (19\%) (Gabriel and Benke-Aberg, 2020, s. 20). Motyw ten pojawił się również w badaniach nad studentami azjatyckiego pochodzenia w USA i Australii (Pham and Shi, s. 7; Morris et al., 2020, s. 92-94). Powyższe skutkowało zamykaniem się części badanych we własnej grupie kulturowej. Doświadczając stresu związanego z pandemią, studenci nie mieli siły na stawianie czoła kolejnym stresorom. Zaczęli szukać oparcia i zrozumienia we własnej - znanej grupie. Mówi o tym student z Turcji:

Nawet bez koronawirusa życie w innym kraju, mówienie obcym językiem, próbowanie przyzwyczajenia się do nowej kultury nie jest wcale łatwe. Podczas koronawirusa to było jeszcze trudniejsze. Zawsze jest trudno żyć w kraju, w którym nie jesteś obywatelem, być „obcym” dla miejscowych. Podczas pandemii to było jeszcze trudniejsze, na przykład gdy mówiliśmy po angielsku, niektóre osoby zakładały maseczki albo krzyczały „koronawirus!”. Każdy patrzył na nas spode łba, ludzie się nas bali. To sprawiło, że czuliśmy się samotni. W pierwszym semestrze byłem zawsze z moimi międzynarodowymi przyjaciółmi. Chciałem poznać inne kultury i języki. Nie tylko z ludźmi z Erasmusa, chciałem 
również zintegrować się z Polakami. Ale w tym semestrze każdy był tak smutny i emocjonalny, a jeśli przechodzisz przez ciężki czas, to jest normalne, że chcesz przebywać z ludźmi, którzy są z twojego kraju i mówią $\mathrm{w}$ twoim języku, ponieważ $\mathrm{w}$ ten sposób łatwiej jest ci wyjaśnić swoje uczucia. Dlatego w tym semestrze generalnie przebywam z moimi tureckimi znajomymi [student X z Turcji na wymianie w Polsce] (badania własne).

$\mathrm{Na}$ problem wycofywania się studentów międzynarodowych z relacji z szerszą społecznością i zamykanie się we własnej grupie kulturowej w czasie pandemii wskutek ataków rasistowskich wskazują również badania australijskie i amerykańskie (Nguyen and Balakrishnan, 2020, s. 3-4; Pham and Shi, 2020, s. 7). Taką izolację można uznać za symptom szoku kulturowego. Jednocześnie jest to przejaw separacji kulturowej. Przejście studentów $\mathrm{z}$ etapu szoku kulturowego do zdrowienia/adaptacji i integracji utrudniają im zarówno obostrzenia, uniemożliwiające szeroko rozumiane kontakty ze społeczeństwem kraju gościnnego, jak i chaos organizacyjno-informacyjny, w jakim znaleźli się oni w czasie pandemii (Gabriels and Benke-Aberg, 2020, s. 11-15). Akulturacja polega na uczeniu się nowej kultury, więc brak dostępu do informacji na temat reguł panujących w obcym kraju jest jednym z głównych czynników utrudniających ten proces.

Ciekawą grupę stanowią studenci, którzy przed pandemią zbliżali się do etapu zdrowienia/adaptacji i byli w trakcie integrowania się ze społeczeństwem przyjmującym. Pandemia zahamowała te procesy. Opowiadają o tym następująco:

Nie mogłem poznawać Szczecina, rozmawiać z ludźmi, poznawać ich, podróżować do innych miast w Polsce i porównać ich ze Szczecinem. Przed pandemią mieliśmy grupę, która spotykała się raz w miesiącu w Instytucie Pedagogiki, żeby oglądać filmy. Przez restrykcje nie mogliśmy więcej tego robić. Jest mi z tego powodu bardzo przykro. Raz w życiu jedziesz na Erasmusa i akurat wtedy ogłaszana jest pandemia [student X z Turcji na wymianie w Polsce] (badania własne).

Tęsknię za moimi przyjaciółmi z Klubu Badmintona. Nie widziałam ich od 20 marca (wówczas Brooklyn College został zamknięty z powodu pandemii). Brakuje mi gry w badmintona. To był mój codzienny rytuał przez ostatnie dwa lata tutaj (...). Po zajęciach przeważnie zostawałam z przyjaciółmi. Teraz nie mogę nawet skorzystać z ksero w bibliotece. Lubię uczyć się w grupie [studentka A z Wietnamu w USA] (Pham i Shi, s. 8). 
Osoby te w czasie „lockdownu” są zmuszone spędzać większość czasu z sublokatorami tej samej narodowości, co powoduje wymuszoną separację kulturową. Nie wynika ona z negatywnych doświadczeń z członkami społeczeństwa przyjmującego, ale z lęku przed zakażeniem. Obrazuje to przykład dwóch mieszkających razem wietnamskich studentek:

Po prostu staramy się chronić siebie przez pozostawanie w domu i modlimy się, żebyśmy nie zostały zainfekowane. Po doświadczeniu pandemii już nie wierzymy w tutejszy system opieki zdrowotnej (...). Zamawiam wszystkie artykuły spożywcze pod drzwi... Nawet nie rozmawiam z moją współlokatorką. Gotuję i wysyłam jej wiadomość, że jedzenie jest w kuchni, kiedy jest głodna. Zamykamy drzwi do naszych pokoi (...). To jest bezpieczne (...). Piszemy do siebie wiadomości, kiedy jest taka potrzeba [studentka A z Wietnamu w USA] (Pham i Shi, s. 8).

Przytoczona sytuacja zaczyna przypominać również marginalizację, a więc stan, w którym traci się kontakt zarówno z przedstawicielami grupy rodzimej, jak i gościnnej. Wymuszoną marginalizację można zauważyć u badanych, którzy na początku pandemii chcieli wrócić do krajów rodzimych, ale z różnych powodów nie mogli tego zrobić, oraz u osób, które nie miały wcześniejszych doświadczeń integracyjnych w społeczeństwie przyjmującym, a „lockdown” zastał ich praktycznie na początku międzynarodowego studiowania. Mówią o tym następująco:

Kiedy kazano nam się przenieść do innego akademika, w tym starym miałem już przyjaciół z całego świata. Nagle część z nich wróciła do domów. Ja zostałem przydzielony do obcych osób, nie miałem kontaktu ze starymi znajomymi. Pilnowano, żebyśmy się nie gromadzili ani nie wychodzili razem do miasta. W kuchni i w pokojach mogły przebywać w tym samym czasie tylko dwie osoby. Dopiero co się poznaliśmy i chcieliśmy się socjalizować, spędzić razem czas, ale nam na to nie pozwalano. Byłem w szoku. Człowiek jedzie na Erasmusa po to, żeby poznawać inny kraj i nowych ludzi. Byłem wściekły i przygnębiony. Nie tak wyobrażałem sobie moją wymianę. Przejechałem pół świata, żeby siedzieć z jedną osobą w pokoju?! Nie mogłem nawet korzystać z biblioteki. Przez pierwsze dwa tygodnie nie miałem siły wstawać z łóżka. Czułem się oszukany przez los [student z Kamerunu na wymianie w Polsce] (badania własne).

Integracja międzykulturowa w dobie izolacji przybiera formę integracji z innymi studentami międzynarodowymi mieszkającymi w tym samym akademiku: 
Okres zamknięcia sprzyjał wytworzeniu się silnych więzi z moimi międzynarodowymi przyjaciółmi. Przed „koroną”, w poprzednim semestrze, różne kultury nie były tak blisko siebie. Nasi polscy koledzy pojechali do domu, byliśmy sami w akademiku, nie wolno nam było podróżować, więc zaczęliśmy sobie nawzajem dawać wsparcie. Mieliśmy wiele problemów, które nas zbliżyły. Staliśmy się rodziną. Myślę, że to dlatego, że ciężkie czasy bardziej łączą ludzi. Tak więc uczyniliśmy ten zły czas dobrym czasem! Nie tylko uczyliśmy się swoich języków, ale również przygotowywaliśmy narodowe potrawy, na tyle, na ile to było możliwe, zachowując dystans społeczny, rozmawialiśmy o naszych krajach i życiach. Zawsze się wspieraliśmy [student Y z Turcji na wymianie w Polsce] (badania własne).

Jednocześnie studenci międzynarodowi wyrażają obawy co do dalszych możliwości integracji zawodowej i edukacyjnej ze społeczeństwami gościnnymi. Spowodowany pandemią kryzys gospodarczy, negatywne zmiany na rynku pracy i w zasadach nauczania stawiają tę kwestię pod znakiem zapytania (Pham i Shi, 2020, s. 7).

\section{Podsumowanie}

W niniejszym artykule przedstawiono przebieg akulturacji i strategie akulturacyjne studentów międzynarodowych w trakcie pandemii COVID-19. Na wstępie tego artykułu postawiono pytanie: czy - parafrazując słowa Gaucheta - pandemia stała się szkłem powiększającym, które uwypukliło niebezpieczeństwa związane z procesem akulturacji studentów międzynarodowych, katalizatorem ukrytych w nim czynników ryzyka i „wyzwalaczem” defektów instytucjonalnych? Przeprowadzona analiza pozwala odpowiedzieć na to pytanie twierdząco. W sposób charakterystyczny dla sytuacji kryzysowej pandemia odarła badanych ze złudzeń dotyczących ich statusu w obcym kraju i odsłoniła integracyjne słabości społeczeństw przyjmujących. Przyśpieszyło to proces akulturacji studentów, którzy w gwałtownym tempie przeszli ze stadium miesiąca miodowego do fazy obserwatora, uczestnika i szoku kulturowego.

Niepokoi fakt, że izolacja pandemiczna oraz chaos informacyjny spowodowany pandemią utrudniają badanym przejście do fazy zdrowienia/adaptacji. U tych, którzy przed pandemią zbliżali się do tego etapu, można zaobserwować zatrzymanie adaptacji i przyjęcie strategii wymuszonej separacji. Studenci wybierają strategie akulturacyjne - lub przez pandemię są skazani na takie wybory - które nie wiążą się z budowaniem relacji ze społeczeństwem 
przyjmującym: separację i marginalizację. Występowanie ostatniej ze wspomnianych jest szczególnie niepokojące ze względu na zdrowie psychiczne badanych. Integracja pojawia się właściwie wyłącznie w kontekście relacji z innymi studentami międzynarodowymi - mieszkającymi w tym samym miejscu.

Jednocześnie studenci wyrażają obawy co do tego, czy pandemia i jej skutki umożliwią im dalszą integrację ze społeczeństwem przyjmującym. Problemy te mogą zaowocować odpływem studentów międzynarodowych z krajów zachodnich, który będzie się utrzymywał nawet po zakończeniu pandemii. Pokazała ona bowiem, że w systemach szkolnictwa wyższego UE, USA i Australii są oni traktowani jako źródło dochodu i zabezpieczenie przed niżem demograficznym. Zabiega się o nich w dobrym czasie, a zostawia samym sobie lub zaleca powrót do domu w czasie złym (Nguyen and Balakrishnan, 2020, s. 2). Aby zapobiec ich odpływowi, potrzebna jest zmiana tego sposobu myślenia.

\section{Bibliografia}

Berry, J.W. 1995. Psychology of acculturation. In: Goldberger, N.R. and Veroff, J.B. eds. The culture and psychology reader. New York: New York University Press, pp. 159-172.

Bochner, S., McLeod, B.M. and Lin, A. 1977. Friendship patterns of overseas students: A functional model. International Journal of Psychology. 12, pp. 277$-297$.

Bochner, S. and Orr, F.E. 1979. Race and academic status as determinants of friendship formation: A field study. International Journal of Psychology. 14, pp. 37-46.

European Migration Network. 2020. EMN INFORM \# 2 - Impact of COVID-19 on international students in EU and OECD member states. Series of EMN-OECD informs on the Impact of COVID-19 in the Migration Area, p. 2. https://www.emn.gov.pl/ese/news/15839,EMN-Inform-2-impact-of-COVID-19-on-international-students-in-EU-and-OECD-member-.html (27.02.2021).

Gabriels, W. and Benke-Aberg, R. 2020. Student Exchanges in Times of Crisis - Research report on the impact of COVID-19 on student exchanges in Europe. Erasmus Student Network AISBL.

Kawula, S. 2012. Pedagogika społeczna dzisiaj i jutro. Toruń: Wydawnictwo Edukacyjne „Akapit”.

Kownacka, E. 2007. Psychologiczne funkcjonowanie migrantów. W: Kownacka, E. red. Podejście wielokulturowe w doradztwie zawodowym. Praktycz- 
ny poradnik dla doradcy zawodowego pracujacego $z$ klientem odmiennym kulturowo. Warszawa: Krajowy Ośrodek Wspierania Edukacji Zawodowej i Ustawicznej, ss. 36-39.

Devecchio, A. 2020. Marcel Gauchet: «Si cette crise pouvait être l'occasion d'un vrai bilan et d'un réveil collectif!». Le Figaro, 25.03.2020. https:// www.lefigaro.fr/vox/societe/marcel-gauchet-si-cette-crise-pouvait-etre-l-occasion-d-un-vrai-bilan-et-d-un-reveil-collectif-20200325 (12.07.2020).

Lysgaard, S. 1955. Adjustment in a foreign society. Norwegian Fulbright grantees visiting the United States. International Social Science Bulletin. 7 (1), pp. 45-50.

Misirlis, N., Zwaan, M. and Weber, D. 2020. International students' loneliness, depression and stress levels in COVID-19 crisis. The role of social media and the host university. https://www.researchgate.net/publication/341668467_International_students\%27_loneliness_depression_and_ stress_levels_in_COVID-19_crisis_The_role_of_social_media_and_the host_university (27.02.2021).

Mok, K.H. et al. 2020. Impact of COVID-19 pandemic on international higher education and student mobility: Student perspectives from mainland China and Hong Kong. International Journal of Educational Research. 105. https://doi.org/10.1016/j.ijer.2020.101718 (28.02.2021).

Morris, A. et al. 2020. The experience of international students before and during COVID-19: Housing, work, study, and wellbeing. Sydney: Institute for Public Policy and Governance. https://apo.org.au/node/307336 (28.02.2021).

Nguyen, O. and Balakrishnan, V.D. 2020. International students in Australia - during and after COVID. Higher Education Research E Development. 39 (7), pp. 1372-1376.

Olszówka, A. i Brzezińska-Hubert, M. red. 2008. Edukacja międzykulturowa. Pakiet edukacyjny Pozaformalnej Akademii Jakości Projektu. Cz. 2. Pozaformalna Akademia Jakości Projektu. Warszawa: Fundacja Rozwoju Systemu Edukacji. Narodowa Agencja Programu „Młodzież w działaniu”. Pham, N.C. and Shi, J.R. 2020. A qualitative study on mental distress of Vietnamese students in the U.S.A in the COVID-19 Era. Asia Pacific Journal of Health Management. 15 (3), pp. 45-57.

UNESCO. 2020. International (or internationally mobile) students. http:// uis.unesco.org/en/glossary-term/international-or-internationally-mobilestudents (27.02.2021). 


\title{
Acculturation of international students during the COVID-19 pandemic
}

\begin{abstract}
This article presents the impact of the COVID-19 pandemic on the acculturation process and acculturation strategies of international students in the UE, USA and Australia. The pandemic has exacerbated difficult and risky aspects of acculturating students and accelerated their acculturation. Epidemic isolation and the information chaos caused by the pandemic make it difficult for students to move from the culture shock phase to the recovery/adaptation phase. Those who were approaching the stage of adaptation prior to the pandemic were stopped and had to adopt the strategy of forced separation. Students choose, or are forced by the pandemic, to take acculturation strategies that do not involve building relationships with the host society: separation and marginalization. Integration, on the other hand, occurs only in the context of integrating with other international students living in the same place. At the same time students express concerns about whether the pandemic and its effects will enable them their further integration.
\end{abstract}

Keywords: international students, COVID-19 pandemic, acculturation, strategies of acculturation 